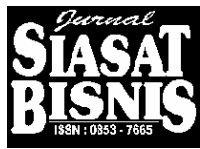

\title{
MERAIH KEUNGGULAN MELALUI PENGINTEGRASIAN PERENCANAAN SUMBER DAYA MANUSIA DAN PERENCANAAN STRATEGIK*)
}

\author{
Eni Andari \\ Fakultas Ekonomi \\ Universitas Janabadra Yogyakarta
}

\begin{abstract}
Abstrak
Proses globalisasi mengakibatkan persaingan dunia usaha menjadi semakin ketat dan tanpa batas. Kemauan untuk bersaing memperebutkan sumber daya manusia dapat menjadi sumber keunggulan kompetitif suatu perusahaan, salah satunya melalui pengintegrasian perencanaan sumber daya manusia dengan perencanaan strategic. Perencanaan sumber daya manusia perlu mengintegrasikan berbagai komponen dan faktor yang ada atau keseluruhan fungsi dalam organisasi/perusahaan sehingga tidak terjebak pada masalah teknis dan hanya berorientasi jangka pendek saja. Peran strategis perencanaan sumber daya manusia dimulai dari analisa kompetensi sumber daya manusia saat ini, kemudian dibandingkan dengan kebutuhan dan kualita sumber daya manusia di masa mendatang.
\end{abstract}

Kata kunci: Globalisasi, keunggulan bersaing, perencanaan strategik, dan perencanaan SDM

PENDAHULUAN

Memasuki abad ke duapuluh satu ini, dunia bisnis menunjukkan kecenderungan yang semakin mengglobal. Konsep globalisasi itu sendiri sebenarnya bukan merupakan hal yang baru tetapi intensitas tantangan di era tersebut cukup besar. Hal ini terlihat dengan semakin banyaknya sumber daya manusia yang pergi melintasi batas-batas negara, dimana angkatan kerja menjadi semakin mobile dan perusahaan semakin menjangkau melintasi batas-batas negara untuk mendapatkan ketrampilan-ketrampilan sesuai yang diinginkan (Johnston, 1991). Sehingga globalisasi tenaga kerja tak terhindarkan lagi. Proses globalisasi ini akan mengakibatkan persaingan dunia usaha menjadi semakin ketat dan tanpa batas. Namun di sisi lain, proses ini juga menuntut perusahaan harus fleksibel untuk merespon secara cepat terhadap perubahan pasar dan persaingan. Perusahaan dapat menarik sumber daya dari luar (outsource) secara agresif untuk meraih efisiensi, serta perusahaan dapat pula memelihara sebagian core competence-nya agar tetap unggul dari pesaing (Porter, 1996). Menurut Porter (1985), terdapat lima faktor yang mempengaruhi terciptanya atau berjalannya suatu persaingan, yaitu:

- Siapa saja dan seberapa banyak perusahaan pesaing yang ada.

*) Pernah diterbitkan pada Jurnal Siasat Bisnis edisi Th. III Vol. 6 Juni 1998 
- Ancaman yang muncul akibat hadirnya pesaing baru.

- Ancaman akibat munculnya produk atau jasa baru.

- Posisi penawaran para pemasok (suppliers).

- Posisi penawaran konsumen (buyers).

Dalam lingkungan yang turbulen sekarang ini memungkinkan perusahaan untuk lebih memerlukan suatu strategi yang mengkhususkan pada keunggulan bersaing untuk mendapatkan pasar bagi produknya (Hayes and Pisano, 1994). Bagi perusahaan-perusahaan yang siap untuk beroperasi secara global, kemauan untuk bersaing memperebutkan sumber daya manusia dapat menjadi sumber keunggulan kompetitif. Sehingga orang merupakan suatu sumber daya inovasi perusahaan yang paling penting (Gupta and Singhal, 1993).

Artikel ini membahas tentang pentingnya perencanaan sumber daya manusia bagi suatu organisasi/perusahaan, proses perencanaan sumber daya manusia, manfaat dan hambatan dalam perencanaan sumber daya manusia, serta pengintegrasian perencanaan sumber daya manusia dengan perencanaan strategic guna membangun keunggulan bersaing bagi perusahaan.

\section{PERAN PERENCANAAN SUMBER DAYA MANUSIA}

Peran strategis perencanaan sumber daya manusia selayaknya dimulai dari analisa kompetensi sumber daya manusia saat ini, kemudian membandingkan dengan kebutuhan dan kualitas sumber daya manusia di masa mendatang. Perencanaan sumber daya manusia strategic lebih menekankan pada peran proaktif dalam fungsi sumber daya manusia, sebagai suatu partner dalam memformulasikan rencana strategic perusahaan, serta memberikan program sumber daya manusia terbaik untuk memastikan pelaksanaan yang efektif dalam perencanaan.

Pada dekade lalu perencanaan sumber daya manusia lebih sekedar merupakan seperangkat teknik dan sistem yang menjadi bagian dari fungsi personalia. Metode perencanaan sumber daya manusia pada awal perkembanganya cenderung berorientasi jangka pendek, sederhana, dan pragmatis. Tidak ada komunikasi dua arah dan keterlibatan karyawan dalam proses perencanaan sangat terbatas. Saat ini perencanaan sumber daya manusia secara luas dipandang sebagai suatu sistem yang dikaitkan dengan organisasi secara keseluruhan. Perencanaan sumber daya manusia tidak lagi hanya menggunakan pendekatan dari atas ke bawah (top down) tetapi juga mulai melibatkan karyawan dengan pendekatan dari bawah ke atas (bottom-up). Perencanaan sumber daya manusia yang baru ini lebih mengoptimalkan komunikasi dua arah dan karyawan terlibat mengoptimalkan komunikasi dua arah dan karyawan terlibat dalam proses perencanaan maupun mempunyai rasa memiliki terhadap perusahaan (Kane and Stanton, 1994). 
Dalam perencanaan sumber daya manusia, perusahaan sering menekankan pada pendekatan top-down, pendekatan bottom-up, atau kombinasi dari keduanya. Kedua pendekatan dalam perencanaan sumber daya manusia tersebut dapat terlihat pada tabel 1 (Walker, 1992).

Perencanaan sumber daya manusia merupakan serangkaian kegiatan yang dilakukan untuk mengantisipasi permintaan-permintaan bisnis dan lingkungan pada organisasi di waktu yang akan datang dan untuk memenuhi kebutuhan-kebutuhan tenaga kerja yang ditimbulkan oleh kondisi-kondisi tersebut (Hani Handoko, 1985). Dalam lingkungan dunia usaha sekarang ini, tingkat persaingan bisnis semakin tinggi dan para pengusaha makin mobile meluaskan jaringan bisnisnya, bukan hanya di negaranya saja tetapi juga di luar negaranya. Kondisi demikian menyebabkan tuntutan pengusaha terhadap karyawan juga semakin tinggi. Namun secara umum perencanaan sumber daya manusia dalam perusahaan memastikan bahwa perusahaan mampu menyelesaikan rencana-rencana bisnisnya. Ketika rencana bisnis ditentukan, sering meminta pertolongan bidang sumber daya manusia dan personalia. Setelah struktur dapat dilaksanakan dan persyaratan individu diidentifikasi, perencana sumber daya manusia mengembangkan program sumber daya manusia dan personalia untuk melaksanakan struktur dan mendapakan tenaga kerja sesuai yang diinginkan.

Oleh karena itu dalam suatu perusahaan, manajer lini dan supervisor bertanggung jawab memberikan informasi yang diperlukan untuk perencanaan sumber daya manusia, dan bekerja dengan manajer sumber daya manusia untuk memastikan bahwa sumber daya manusia perusahaan dapat digunakan secara efektif. Secara khusus, perencanaan sumber daya manusia dapat digunakan untuk: (Schuler and Huber, 1993).

- Mengurangi biaya personal dengan membantu manajemen mengantisipasi kekurangan atau kelebihan sumber daya manusia dan memperbaiki ketidakseimbangan sebelum mereka menjadi tidak dapat diatur dan mahal.

- Memberikan suatu dasar yang lebih baik untuk pengembangan perencanaan karyawan yang membuat opimum atas sikap pekerja.

- Memperbaiki proses perencanaan bisnis keseluruhan.

- Memberikan peluang yang sama bagi pria dan wanita, anggota dalam kelompok minoritas dan mayoritas, dan individu dengan tanpa cacat fisik dalam perencanaan pertumbuhan di masa datang.

- Mengembangkan kesadaran yang lebih besar dalam kepentingan suara manajemen sumber daya manusia melalui semua level organisasi.

- Memberikan suatu alat untuk menilai dampak kebijakan dan tindakan manajemen sumber daya alternatif. 
Tabel 1. Pendekatan Perencanaan Sumber Daya Manusia

\begin{tabular}{|c|c|c|}
\hline & Perencanaan Top Down & Perencanaan Bottom-up \\
\hline Tujuan & Memberikan konteks strategic & Merencanakan tindakan tertentu \\
\hline Pendekatan & Mengalir dari corporate ke divisi & $\begin{array}{l}\text { Bergulir dari divisi dengan tinjauan } \\
\text { corporate }\end{array}$ \\
\hline Horisn waktu & Jarak jauh & Jarak pendek \\
\hline Analisis Lingkungan & $\begin{array}{l}\text { Bagian atau parallel dengan peni- } \\
\text { laian lingkungan untuk strategi } \\
\text { bisnis }\end{array}$ & $\begin{array}{l}\text { Pengidentifikasian persoalan dalam } \\
\text { konteks persoalan dan trend-trend } \\
\text { strategic }\end{array}$ \\
\hline Analisis Implikasi & $\begin{array}{l}\text { Penilaian implikasi sumber daya } \\
\text { manusia dalam perencanaan oleh } \\
\text { manajer dan staf sumber daya } \\
\text { manusia }\end{array}$ & $\begin{array}{l}\text { Penilaian implikasi sumber daya } \\
\text { manusia dalam perencanaan oleh } \\
\text { manajer dan staf sumber daya } \\
\text { manusia }\end{array}$ \\
\hline Perencanaan Integral & $\begin{array}{l}\text { Bagian dari proses perencanaan } \\
\text { bisnis atau bagian dari proses } \\
\text { sumber daya manusia menuju } \\
\text { persoalan yang berhubungan } \\
\text { dengan orang }\end{array}$ & $\begin{array}{l}\text { Penganalisaan, peramalan, pe- } \\
\text { rencanaan persoalan spesifik atau } \\
\text { subyek yang sesuai }\end{array}$ \\
\hline Pengawasan dan Penilaian & & $\begin{array}{l}\text { Memonitor dan pelaporan atas } \\
\text { kemajuan dalam persoalan pe- } \\
\text { mecahan masalah }\end{array}$ \\
\hline
\end{tabular}

\section{PROSES PERENCANAAN SUMBER DAYA MANUSIA}

Perencanaan sumber daya manusia lebih dipandang sebagai suatu proses manajemen daripada hanya semata-mata sebagai fungsi staf personalia. Sesuai dengan proses perencanaan sumber daya manusia, sebagai pencerminan proses perencanaan bisnis, harus mempertimbangkan hubungan jangka panjang dan jangka pendek. Terdapat empat fase dalam perencanaan sumber daya manusia, yaitu: (Schuler and Huber, 1993).

- Fase 1: Pengumpulan, Penganalisaan, dan Peramalan Penawaran dan Permintaan data.

Fase ini meliputi pengembangan data yang dapat digunakan untuk menentukan tujuan, rencana-rencana serta kebijakan sumber daya manusia. Data yang dikembangkan dalam fase ini merupakan informasi yang diperoleh pada masa lalu, diamati pada saat ini, dan diramalkan untuk masa mendatang. Terdapat empat tahap dalam fase 1 , yaitu: (1) menganalisis sumber daya manusia, (2) meramalkan permintaan sumber daya manusia, (3) menyesuaikan anggaran, dan (4) meramalkan penawran sumber daya manusia. Setiap tahap sangat penting bagi keberhasilan pemrograman dan perencanaan sumber daya manusia. 
- Fase 2: Menggambarkan Kebijakan dan Tujuan Sumber Daya Manusia Karena lingkungan usaha menjadi lebih tidak pasti dan sulit diprediksi, maka tujuan dan kebijakan perusahaan cenderung mempunyai harapan jangka pendek daripada sebelumnya. Hal ini akan berdampak pada pendesainan program manajemen sumber daya manusia. Sehingga perusahaan perlu menghubungkan perencanaan dan tujuan sumber daya manusia dengan kebutuhan dan rencana bisnis.

- Fase 3: Pemrograman Sumber Daya Manusia

Tindakan pemrograman didesain untuk meningkatkan penawaran karyawan yang tepat dalam perusahaan atau mengurangi jumlah karyawan. Saat ini perusahaan akan menggunakan berbagai alternatif program yang disesuaikan dengan tujuan, seperti pembedaan program untuk membuat organisasi lebih menarik bagi pelamar, program memperbaiki usaha-usaha sosialisasi sehingga karyawan yang baik berkeinginan tetap tinggal di perusahaan, dan program downsize atau righsize organisasi.

- Fase 4: Penilaian dan Pengawasan - Perencanaan Sumber Daya Manusia

Pelaksanaan program sumber daya manusia harus dimonitor dan dinilai. Fase ini sangat penting untuk pengelolaan sumber daya manusia secara efektif. Penilaian atas program dan rencana sumber daya manusia merupakan suatu proses penting tidak hanya untuk menentukan efektifitas perencanaan sumber daya manusia tetapi juga untuk menunjukkan signifikansi baik dalam perencanaan sumber daya manusia dan personalia dengan bidang sumber daya manusia dalam organisasi sebagai suatu keseluruhan.

Perencanaan sumber daya manusia merupakan suatu proses perencanaan yang berbeda dan terpisah. Bagian sumber daya manusia tidak hanya memprakarsai usaha-usaha tetapi mendesain dan mengelola perencanaan sumber daya manusia. Sehingga perencanaan sumber daya manusia lebih merupakan suatu proses untuk membentuk sumber daya manusia daripada memprioritaskan bisnis.

\section{MANFAAT DAN HAMBATAN PERENCANAAN SUMBER DAYA MANUSIA}

Menghadapi kondisi masa depan yang semakin tidak pasti, maka perlu perencanaan dan penggunaan sumber daya manusia yang dapat membeirkan manfaat yang maksimal. Perencanaan sumber daya manusia yang matang memungkinkan adanya manfaat yang dapat dipetik perusahaan secara mantap, yaitu: (Siagian, 1997)

- Organisasi dapat memanfaatkan sumber daya manusia yang sudah ada dalam organisasi secara lebih baik. Berarti perencanaan sumber 
daya manusia perlu diawali dengan kegiatan inventarisasi tentang sumber daya manusia yang sudah terdapat dalam organisasi.

- Melalui perencanaan sumber daya manusia yang matang, produktivitas kerja dari tenaga yang sudah ada dapat ditingkatkan. Hal ini dapat dilakukan melalui penyesuaian-penyesuaian tertentu, seperti peningkatan disiplin kerja dan ketrampilan sehingga setiap orang menghasilkan sesuatu yang berkaitan langsung dengan kepentingan organisasi.

- Perencanaan sumber daya manusia berkaitan dengan penentuan kebutuhan akan tenaga kerja di masa depan. Hal ini dimaksudkan agar organisasi memperoleh tenaga-tenaga yang benar-benar sesuai dengan kebutuhan.

- Salah satu segi manajemen sumber daya manusia yang dewasa ini dirasakan semakin penting ialah penanganan informasi ketenagakerjaan. Informasi ini diperlukan tidak hanya oleh satuan kerja yang mengelola sumber daya manusia dalam organisasi, akan tetapi juga oleh setiap satuan kerja.

- Perencanaan sumber daya manusia akan menimbulkan pemahaman yang tepat tentang situasi pasar kerja.

- Rencana sumber daya manusia merupakan dasar bagi penyusunan program kerja bagi satuan kerja yang menangani sumber daya manusia dalam organisasi. Tanpa perencanaan sumber daya manusia, sulit untuk menyusun program kerja yang realistik.

Dalam melakukan perencanaan sumber daya manusia sering perusahaan akan menghadapi berbagai hambatan, antara lain: (Stanton and Kane, 1991).

- Tidak dapat diidentifikasinya suatu kebutuhan untuk perencanaan jangka panjang, karena manajer puncak cenderung mengadopsi suatu orientasi jangka pendek.

- Kurangnya dukungan terhadap perencanaan sumber daya manusia, karena para manajer puncak kurang memprioritaskan pada masalah manajemen sumber daya manusia.

- Kurang jelasnya pengintegrasian fungsi manajemen sumber daya manusia.

HUBUNGAN PERENCANAAN SUMBER DAYA MANUSIA DENGAN PERENCANAAN STRATEGIK

Strategi sumber daya manusia merupakan strategi fungsional, sama seperti bidang lainnya - keuangan, informasi, dan pemasaran. Dalam beberapa perusahaan, perencanaan fungsional jangka panjang (untuk sumber daya manusia, keuangan, sistem informasi, teknologi dan sebagainya) merupakan suatu elemen tugas dalam proses perencanaan bisnis jangka panjang. 
Perencanaan sumber daya manusia dapat menjadi strategik (jangka panjang dan umum) atau taktik (jangka pendek dan khusus). Pada level perencanaan strategic, perencanaan sumber daya manusia terkait dengan persoalan-persoalan seperti penilaian implikasi manajemen dalam kebutuhan bisnis di masa mendatang, penilaian faktor eksternal dalam perusahaan dan pengukuran penawaran internal karyawan dalam jangka panjang. Fokus perencanaan strategic di sini untuk menganalisa persoalan, bukan membuat proyeksi yang mendetail. Pada level operasional, atau taktik, perencanaan, perencanaan sumber daya manusia terkait dengan peramalan secara detail dalam penawaran karyawan. Berdasarkan peramalan ini, perencanaan tindakan tertentu dapat dijalankan. Hal ini melibatkan penarikan, decruitment, promosi, pelatihan, atau transfer. Prosedur harus digambarkan untuk mengawasi dan menilai kemajuan ke arah tujuan yang diinginkan. Perencanaan sumber daya manusia memfokuskan pada tanggapan level perusahaan ke persoalan-persoalan bisnis yang terkait dengan orang-orang atas horizon waktu multiple (Cascio, 1992).

Dalam perencanaan sumber daya manusia tradisional biasanya diprakarsai dan dikelola oleh bagian sumber daya manusia. Namun dalam perencanaan sumber daya manusia strategic akan melibatkan juga top manajemen serta para ahli sumber daya manusia serta mempercayakan informasi pada berbagai level manajemen (Fisher, 1993). Suatu perencanaan sumber daya manusia adalah strategik apabila perencanaan tersebut membantu manajemen mengantisipasi dan mengelola perubahan secara cepat. Strategik sumber daya manusia berarti persekutuan manajemen sumber daya manusia dengan konteks strategic dalam bisnis. Sedangkan suatu strategi bisnis menunjukkan arahan keseluruhan dalam suatu bisnis di bawah kondisi perubahan (Walker, 1992). Perencanaan strategic meliputi serangkaian langkah yang setiap langkahnya mungkin melibatkan pengumpulan data yang banyak sekali, analisis, dan penilaian yang berulang-ulang.

Menghubungkan perencanaan sumber daya manusia dengan perencanaan strategik bisnis dalam suatu perusahaan tidaklah mudah. Walker merekomendasikan lima langkah pendekatan untuk menghubungkan proses tersebut. Kelima langkah tersebut meliputi: (Simamora, 1995

- Mendefinisikan filosofi perusahaan.

- Langkah ini dimaksudkan untuk mengetahui tujuan perusahaan berdiri, kontribusi yang dibuat, maupun motif yang mendasari para manajer kunci.

a Menelaah kondisi lingkungan.

- Langkah ini berupaya untuk mengetahui peluang atau ancaman yang muncul dalam suatu perubahan yang kemungkinan dapat mempengaruhi arah mendatang dalam suatu bisnis. 
- Menentukan tujuan dan sasaran.

- Pertanyaan yang berkaitan dengan langkah ini menyangkut tujuan penjualan, laba, dan kembalan investasi serta dasar untuk mengukur tujuan tersebut.

a Menyusun strategi.

- Fokusnya pada penentuan tindakan yang harus dilakukan perusahaan untuk mencapai tujuan yang telah ditetapkan.

Keterkaitan antara perencanaan bisnis dan perencanaan sumber daya manusia dapat dilihat dalam Tabel 2: (Casio, 1992).

Tabel 2. Dampak Tiga Level Perencanaan Bisnis dalam Perencanaan Sumber Daya Manusia




Teori perencanaan sumber daya manusia telah berkembang cukup pesat ke arah suatu proses perencanaan sumber daya manusia jangka panjang yang sepenuhnya terintegrasi dengan proses perencanaan bisnis strategis jangka panjang dan mengintegrasikan beragam fungsi manajemen sumber daya manusia secara ideal. Golden dan Ramanujam mengajukan keterkaitan integrative antara perencanaan sumber daya manusia dengan bisnis jangka panjang sebagai suatu proses perencanaan strategis antara aktivitas-aktivitas sumber daya manusia secara total dengan perencanaan fungsional dan pembuatan keputusan lain, dan staf sumber daya manusia diterima sebagai mitra sepenuhnya dalam organisasi.

Terdapat berbagai persyaratan untuk pengintegrasian perencanaan sumber daya manusia, yaitu: (Stanton and Kane, 1991).

1. Penganalisaan lingkungan eksternal organisasi dan strategi keseluruhan untuk menentukan kemungkinan menerapakan perencanaan strategi terpusat dan berjangka panjang untuk organisasi.

2. Perlu komitmen pengembangan rencana dari manajer untuk menggunakan perencanaan sumber daya manusia strategic. Hal ini dapat dilakukan apabila perencanaan strategis jangka panjang sesuai dengan lingkungan dan tujuan organisasi.

3. Manajemen puncak perlu mengakui bahwa masalah sumber daya manusia pantas mendapat prioritas sama dengan masalah yang lebih tradisional, seperti modal, peralatan dan sebagainya, sebelum pendekatan terintegrasi penuh dapat diterima.

4. Organisasi harus menyediakan staf, waktu dan sumber daya lain untuk menyusun, menerapkan dan memonitor rencana sumber daya manusia.

5. Perlu pengembangan sistem informasi sumber daya manusia.

6. Dimanapun fungsi perencanaan sumber daya manusia dilokasikan perlu bekerja sama dengan fungsi perencanaan $a b$.

7. Fungsi perencanaan sumber daya manusia perlu mempertahankan hubungan yang erat dengan aspek-aspek lain dari fungsi manajemen sumber daya manusia sehingga kebijakan-kebijakan dan aktivitas-aktivitas dalam bidang seperti perekrutan, seleksi, dan penilaian staf, pelatihan dan pengembangan, pengembangan karir, pembayaran dan tunjangan yang mendukung pencapaian tujuan rencana sumber daya manusia.

\section{PENUTUP}

Sejalan dengan perubahan fungsi manajemen sumber daya manusia menuju manajemen sumber daya manusia strategic, maka perencanaan sumber daya manusia dalam perusahaan mengalami perkembangan ke arah yang sama. Perencanaan sumber daya manusia ini dilakukan 
untuk mengantisipasi bisnis di masa mendatang. Perencanaan sumber daya manusia diharapkan tidak terjebak pada masalah teknis dan hanya berorientasi jangka pendek saja, tetapi juga perlu mengintegrasikan berbagai komponen dan faktor yang ada atau keseluruhan fungsi dalam organisasi/perusahaan. Salah satu implikasi perencanaan sumber daya manusia antara lain perlunya perusahaan mempertimbangkan lebih lanjut ke arah perencanaan sumber daya manusia strategik. Dengan demikian melalui perencanaan sumber daya manusia strategik diharapkan perusahaan akan benar-benar mendapatkan sumber daya manusia yang berkualitas sesuai kebutuhan.

Peran strategis perencanaan sumber daya manusia selayaknya dimulai dari analisa kompetensi sumber daya manusia saat ini, kemudian dibandingkan dengan kebutuhan dan kualita sumber daya manusia di masa mendatang. Sehingga tanpa adanya suatu perencanaan sumber daya manusia, maka tujuan perusahaan atau perencanaan bisnis akan semakin sulit dicapai.

\section{DAFTAR PUSTAKA}

Cascio, Wayne F., 1992, Managing Human Resource: Productivity, Quality of Work Life, Profits, Mc-Graw Hill international Edition, Management Series, Third edition, Singapore.

Fisher, Cynthia D.; Schoenfeldt, Lyle F., and Shaw, James B., 1993, Human Resource Management, Hougton Mifflin Company, USA.

Gupta, Ashok K., and Singhal Arvind, 1993, Managing Human Resources For Innovation and Creativity, Harvard Business Review, MayJune, pp. 41-48.

Hani Handoko, 1985, Manajemen Personalia dan Sumber Daya Manusia, Liberty, Yogyakarta.

Hayes, Robert H., and Pisano Gary P., 1994, Beyond World-Class : The New Manufacturing Strategy, Harvard Business Review, JanuaryFebruary,pp. 77-86.

Johnston, William B., 1991, Global Work Force 2000: The New World labor Market, Harvard Business Review, March-April, pp. 115-127.

Kane, Robert L., and Susan Staton, 1994, Human Resource Planning: Where are We Now, Asia Pasific Human Resource Management, Winter, Vol. 29, No. 2, pp. 39-53.

Porter, Michael E., 1985, Competitive Advantage, New York: Free Press. 
Porter, Michael E., 1996, What is Strategy, Harvard Business Review, November-December, pp. 61-78.

Schuler, Randall S., and Huber, Vandra L., 1993, Personnel and Human Resource Management, Third Edition, West Publishing Company, USA.

Sondang P. Siagian, 1997, Manajemen Sumber Daya Manusia, Bumi Aksara, Jakarta.

Walker, James W., 1979, Human Resource Planning: An Evolution, Pittsburgh Business Review, Vol. 47, No. 1, March, pp. 288-303.

Walker, James W., 1992, Human Resource Strategy, Mc.Graw Hill Series in Management, USA. 